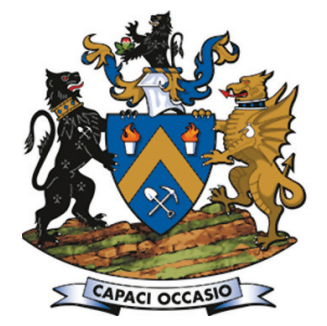

\title{
A mining perspective on the potential of renewable electricity sources for operations in South Africa Part I-The research approach and internal evaluation process
}

\author{
by R.G. Votteler* and A.C. Brent ${ }^{\dagger}$
}

\section{Synopsis}

The business performance of mining corporations in South Africa is adversely affected by the constantly increasing electricity costs. The most commonly used power sources are the national utility supplier via a grid connection, and on-site diesel generators. Previous research has identified the renewable sources of solar photovoltaic (PV), onshore wind, and geothermal energy in hybrid versions with current sources as possible opportunities to counteract rising electricity costs. To provide a clear understanding of the new, developing market of renewable energy sources, this research is divided into two papers. This first paper investigates the internal business structure of mining corporations in order to evaluate electricity generating sources. The multi-criteria decision analysis (MCDA) method is selected as the most suitable approach for this. The paper identifies the criteria used by mining corporations to evaluate possible electricity generation sources for self-generation by means of the corporations' own investment. Four mining corporations with several mining locations were interviewed. The interviews revealed both new and identical evaluation criteria when the findings were compared to earlier MCDA adaptations analysed in the literature review. The second paper (Part 2) combines current knowledge about the external macroeconomic environment with the findings about the internal environment described here. MCDA is adapted in Part 2 and implemented to analyse and compare current to hybrid renewable sources from the perspective of mines.

Keywords

Multi-criteria decision analysis, South Africa, renewable electrical energy, mining.
2018 (Numbi et al., 2014; Eskom, 2015b). In addition, the South African government plans to introduce a carbon tax on greenhouse gas emissions (Alton et al., 2014).

The use of renewable sources of energy has the potential to be an opportunity for mining corporations to reduce long-term electricity costs, diversify energy supply, be less affected by fuel price volatility, decrease greenhouse gas emissions, and show 'green leadership' (Nicolas, 2014). The combination of technological progress regarding renewable sources and factors in the external environment, like increasing fossil fuel prices and social pressure to become greener, increases the attractiveness of renewable sources for mining corporations (Roehrl and Riahi, 2000).

Mining corporations are relatively new customers for renewable energy companies, whose current target customers are mostly governmental organizations and smaller private bodies. Moreover, mining corporations have to be more informed about renewable energy technologies and the possible fit to their specific needs. To optimize the learning process for mining corporations to understand renewable energy technologies, and for energy companies to learn how to approach these potential new customers, more research has to be conducted (Steinhaeuser et al., 2012). One of the outcomes of several renewables and mining summits ${ }^{2}$ worldwide is the realization that mining corporations have to become better educated about the concept of renewable energy sources in the context of their unique operational demands (Judd, 2014).

* School of Public Leadership, Faculty of Economic and Management Sciences, Stellenbosch University, South Africa.

+ Centre for Renewable and Sustainable Energy Studies, Department of Industrial Engineering, Stellenbosch University, South Africa and Sustainable Energy Systems, Engineering and Computer Science, Victoria University of Wellington, New Zealand.

(C) The Southern African Institute of Mining and Metallurgy, 2017. ISSN 2225-6253. Paper received Sep. 2015; revised paper received Jun. 2016. 


\section{A mining perspective on the potential of renewable electricity sources-Part 1}

The purpose of this paper is to contribute more knowledge to this learning process. Previous research has been directed only at analysing the external macroeconomic framework for renewable sources relating to mining operations in South Africa (Votteler and Brent, 2016). The contribution of this paper is to investigate the internal business approach of mining corporations in evaluating electrical energy sources. A strategic method is used to structure the research, as the existing theory and previous applications create a greater research foundation through experience, and which ensures that all aspects are considered in order to to achieve the research objectives. The findings of this paper about the internal evaluation process represent the foundation for future research; with the aim of ultimately combining it with current knowledge about the external framework.

This is the first of two papers on these topics. The reason for dividing the work is initially to create a solid foundation, which is reflected in the structure of this paper. The next section illustrates the research methodology, and this is followed by the selection of an appropriate research approach and an examination of how past applications can contribute to this research. The internal evaluation process of mining corporations is then investigated. Finally, the research results are presented. The objectives are illustrated in Figure 1. The second paper implements the selected research approach from a mining perspective, with the final result of a clear evaluation and comparison of how renewable and current sources perform for mining corporations in South Africa.

\section{Research methodology}

\section{Literature review}

The first objective was to identify the most suitable method. Based on the work of Petticrew and Roberts (2006), a systematic review was used to comprehensively investigate possible options. Firstly, the paper states the requirements that the method has to fulfil to obtain the best possible solution to the main objective. Research was conducted to select three methods that are most likely to contribute to the requirements. The three methods are introduced and analysed according to the requirements. The last section introduces the selected method and provides the reasoning.

The second objective of this paper was to identify previous approaches of method selection in energy planning in similar cases. Based on Petticrew and Roberts (2006), a state-of-the-art review was conducted. Firstly, previous

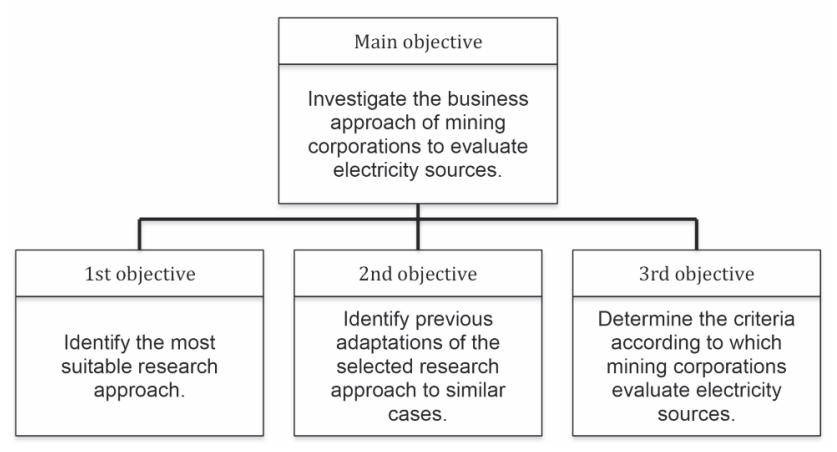

Figure 1-Research objectives publications in the energy planning field were sourced and key characteristics contained therein were tabulated. The aim was to investigate the areas in which research had already been conducted, and those in which new adaptations had to be made for the purpose of this research. Secondly, an overview is provided of the results generated in the publications identified. The overview was of assistance in the interviews with mining corporations, as basic background knowledge of applications in similar cases.

The aim was to provide a substantial overview of the selected research methods in energy planning that were implemented between 2001 and 2015. Subsequently, 26 different papers were identified; 13 purely from a renewable energy perspective, and 13 from a mixed conventional/renewable energy perspective.

\section{Semi-structured interviews}

A qualitative research focus was applied in the form of semistructured interviews. The reason for this approach was the exploratory form of the research. The research included a sample of four different mining corporations. The respondents were decision-makers or people who knew all about the criteria that the corporation used to evaluate possible electricity sources. The respondents were firstly interviewed face-to-face to elicit the information about the evaluation process. The main part of the interview used a post-it session to generate all information in a structured manner. The semi-structured interview questionnaire ensured that all aspects were considered in the session (Newton, 2010).

The identified criteria were used to construct a decision criteria table, which illustrated all the relevant criteria that the mining corporation used to evaluate possible electricity sources. The transformation from the mind-map to the table was conducted according to the requirements for criteria, which are enumerated later. A Delphi technique was used, which meant sending the constructed table back to the respondents via e-mail to obtain confirmation that it reflected their practices accurately. The Delphi technique is in essence a series of sequential rounds-interspersed with controlled feedback - that seek to gain the most reliable consensus of opinion of a group of experts (Powell, 2003).

\section{The questionnaire}

A semi-structured interview questionnaire was set up to collect the necessary information for the third research objective. As no approach using the selected method for energy planning from a corporate perspective was found, a qualitative exploratory research technique was used to identify the evaluation criteria. Firstly, the questionnaire would draw accurate information from respondents. Secondly, it would provide structure to the interview. Thirdly, it would provide standards from which facts, comments, and attitudes could be recorded. Lastly, it would facilitate data processing, as answers would be recorded in a common place on each questionnaire (Hague and Jackson, 1995).

\section{Method selection}

\section{Requirements of the method}

The reason for using a strategic method as the foundation of this research is firstly the existing theory. Extensive academic 


\section{A mining perspective on the potential of renewable electricity sources-Part 1}

research has been done to ensure that the method considers all aspects regarding its overall purpose. Therefore, it provides more assurance in respect of this research that all aspects are investigated. Secondly, previous applications in similar cases contribute to a greater understanding of how the objectives can be met.

This section describes the requirements of the strategic method to best address the main research objective of this paper, namely: to investigate the business approach of mining corporations in evaluating and selecting electricity sources. The requirements were to be used to find the most appropriate basis for research. To be able to successfully investigate the main objective, the strategic method needed to fulfil the following requirements:

> To provide information to mining corporations about the concept of renewable energy in the context of their own unique usage patterns. As described in the Introduction, recent developments have increased the attractiveness of renewable energy. Consequently, research has to be conducted to illustrate to mining corporations how this could fit their specific needs

$>$ To add to the knowledge of renewable energy companies about the needs and business structure of this new type of customer, namely mining corporations. The approach has to create a greater understanding of renewable energy companies and how best to customize the information about electricity sources to the specifications of mining operations

> To investigate the strengths and weaknesses of selected electricity sources. The approach has to be able to contribute to the reasoning why a selected electricity source has or has not been considered appropriate for mining operations. The weaknesses should illustrate what potentially has to change to make it more attractive

> To compare different selected electricity sources according to the specific needs of mining operations. It should be possible to illustrate why certain sources have provided a better fit for mining operations than others. The comparison between currently used and new technologies adds to a better understanding.

\section{Possible methods}

This section lists different popular methods that could possibly assist to structure the research. All methods listed in Table I were considered and investigated. The MCDA, the balanced scorecard (BSC), and strategic planning methods were found to be most likely to contribute to the characteristics listed in the previous section. Table I illustrates which requirements the three selected methods fulfilled. The numbers in the top row are linked to the requirements described in the previous section.

Each of the three selected methods is briefly introduced, a possible utilization is described, and a contribution according to these characteristics is discussed.

\section{Strategic planning approach}

A strategic planning (SP) model is a tool for businesses to organize their current operations in order to realize the desired future. The model can be seen as a roadmap for the business to get from where it is now to where it wants to be. It is of importance for businesses to create a plan, as it provides clarity on how to achieve the planned goal (King and Cleland, 1987). Every strategic planning model should incorporate seven elements: plan-to-plan (rarely used); mission; needs assessment; strategic objectives; outcome measures; strategies; and performance feed-forward (De Beer, 2000).

The SP approach can be adapted and implemented according to the main research objective. A mining corporation should express in its strategic mission statement the aim to diversify its electricity mix and should specifically set out its approach to adopting renewable sources (Cetindamar et al., 2013).

A shortcoming of the SP approach is that it does not identify strengths and weaknesses, nor does it compare the selected technologies according to the specific demand requirements of mining corporations. Furthermore, it will be influenced strongly by the mining corporations' strategic aims. Another shortcoming - relevant to this paper - is the more strategic nature of the SP approach to improve a company's business coordination (Jakhotiya, 2013). The objective of this research is oriented towards a once-off decision.

\section{Balanced scorecard approach}

The balanced scorecard (BSC) is a tool that converts the strategy and mission of an organization into qualitative and quantitative performance indicatorss. The indicators provide the structure for an effective, dynamic, and timely strategic management and measurement system to achieve the overall strategy (Westermann and Sehl, 2006). The scorecard approach identifies elements and requirements that have to be considered in order to follow the strategy with the best possible outcome. The original Balanced Scorecard of Robert Kaplan and David Norton (1992) entails four scoring

\begin{tabular}{|c|c|c|c|c|}
\hline \multicolumn{5}{|c|}{$\begin{array}{l}\text { Table I } \\
\text { Possible strategic methods }\end{array}$} \\
\hline Method & Requirement 1 & Requirement 2 & Requirement 3 & Requirement 4 \\
\hline Multi-criteria decision analysis 1 & $\checkmark$ & $\checkmark$ & $\checkmark$ & $\checkmark$ \\
\hline Balanced scorecard2 & $\checkmark$ & $x$ & $\checkmark$ & $\times$ \\
\hline Strategic planning ${ }^{3}$ & $\checkmark$ & $\checkmark$ & $x$ & $x$ \\
\hline
\end{tabular}




\section{A mining perspective on the potential of renewable electricity sources-Part 1}

elements: financial, customer, internal business processes, and learning and growth (Linard and Yoon, 2000).

The BSC principle could have been used to fulfil the main research objective of this paper, with some adaptation for mining corporations that have the goal of becoming involved in renewable energy sources. The adaptation and application would contribute to providing information to mining corporations, as it would show all the criteria that a mining corporation has to fulfil to realize such a project. The BCS approach would contribute to informing mining corporations about renewable energy by illustrating the main requirements that have to be fulfilled when realizing on-site renewable energy projects. The mining corporation would be able to understand in which areas adjustments have to be made or, perhaps, that no realization of objectives would be possible as the requirements are simply not achievable.

The shortcoming here is that the requirements are not based on the specific needs of a mining corporation. Furthermore, the fact that the requirements are based on what the technology can supply, rather than on the demands of the mining corporation, make comparisons difficult as the requirements might differ.

Another problem is that the BSC approach requires the mining corporations to have the initial strategic goal of getting involved in renewable energy (Person, 2013). As the market is still relatively new, mining corporations first have to be informed about the possibilities of renewable energy in catering for their specific needs (Chislett, 2014).

Consequently, with adapting and applying the BSC, the criteria used are based on the technology's specification and not the mining corporations' perspective, which limits the informative data. The approach should not illustrate the requirements to realize the technology, but rather how it would work based on the mining corporations' needs.

\section{Multi-criteria decision analysis}

Multi-criteria decision analysis (MCDA) is a method that is utilized in making complex decisions. When making complicated decisions it is necessary for the decision-makers to handle a large number of criteria that influence the decision. The MCDA method assists the decision-makers to select the best possible alternative (Ishizaka and Nemery, 2013). The MCDA process is generally divided into three main steps: problem structuring, model building, and approval of the model (Stewart and Belton, 2002).

It was found that the MCDA method could be adapted to the context of the main research objective as it could illustrate to mining corporations which selection among electricity sources would be most suitable. The method would achieve this by utilizing the mining corporations' own evaluation criteria. Firstly, the research would identify the criteria that mining corporations use to evaluate possible electricity sources. Secondly, the type of electricity source and possible uncertainties in the internal and external environment would be identified. Thirdly, based on the identified criteria, an MCDA method would have to be developed to analyse different electricity-generating technologies. The most likely and attractive technologies could then be analysed and evaluated.

The MCDA method developed for the purpose of this research would contribute to providing information to mining corporations by indicating the possible fit of renewable energy. The corporations would be able to understand, according to their own evaluation criteria, what the use of renewable energy entails. However, the method would be developed according to a specific type of electricity source to ensure that the same criteria can be used-which would limit the applicability to technologies. Possible different types of technologies are self-generating sources, like diesel generators, and tri-generation systems, like combined heat and power (CHP).

The renewable energy company would gain more understanding of how mining corporations evaluate such projects. Consequently, it would ease communication about a possible project realization, as information packages about the technology can be customized from the beginning.

The MCDA method enables the mining corporation to identify the strengths and weaknesses of the selected technologies from its own point of view (Stewart and Belton, 2002). A clearer understanding of how the new technologies would perform compared to the present ones would be obtained. It would be possible to compare, according to each criterion, how the different alternatives perform. Close attention has to be paid, however, to ensuring that no external influences are neglected.

\section{Selection of strategic method}

The MCDA technique was selected as the most appropriate method to investigate the main research objective. The technique evaluates and analyses electricity options from the perspective of mining corporations. The other two approaches would require the initial aim of the mining corporations to be to implement renewable energy, and would not analyse the technologies according to the mines' own criteria. As the market for renewable sources of electricity is still in its infancy (Chislett, 2014), the MCDA method was considered more suitable.

The renewable energy company would be able to gain the most valuable information from the MCDA method, as it identifies the criteria and structure that are important to mining corporations. In addition, as the technology is new for mining corporations and not for the renewable energy company, it would be more beneficial to analyse the strengths and weaknesses and to compare the technologies from the perspective of the mining corporations.

Another reason is that the SP and BSC approaches are more oriented towards the successful realization of a business strategy than of a physical project. The BSC aims to continually measure, according to selected criteria, how close the performance is to the overall strategic goal. The research content of this paper, on the other hand, aims for a once-off decision.

Lastly, the SP approach involves the investigation of the different technologies, the internal issues, the external influences, the market potential, and a possible scenario analysis. As the market is still in its infancy, the key focus should be on the education of the mining corporations.

\section{Existing applications to similar cases}

\section{Previous MCDA approaches to energy planning}

To be able to gain an overview and an understanding of how MCDA approaches have been used in energy planning in 


\section{A mining perspective on the potential of renewable electricity sources-Part 1}

recent years, a literature review was conducted. Twenty-six other approaches were identified and summarized in the same way as the MCDA approaches were used, namely according to publication year, energy alternatives selected, final ranking of alternatives, type of criteria used, types of alternatives, main stakeholder (perspective), project size, source of criteria used, and the area of implementation. The results are represented in Table II.

The points below introduce each column in Table II and provide a brief summary of the findings:

> Column 1 firstly enumerates each article of the 26 articles, with the purpose of using them to review the criteria used in energy-planning MCDA approaches (Table III). Secondly, the selection of past MCDA approaches was divided in half: 13 mixed electricity alternatives and 13 purely renewable alternatives. The main reason was to illustrate if there were differences in the selection of the evaluation criteria, which are shown in Table III. Mixed alternatives, besides renewable energy, include other non-renewable energy sources like nuclear, coal, and/or other fossil fuels

> Column 2 gives the author and the publication year of the study. Nineteen $(73 \%)$ of the 26 articles were published between 2009 and 2014, with the oldest in 2001

> Columns 3 and 4 name all electricity alternatives that were analysed by the MCDA. In the mixed alternatives, i.e. articles 1 to 13, the most frequently nominated alternative was wind with 12 , followed by solar (11), hydro (11), gas (11), nuclear (10), and coal (9). In nine of the 13 articles, rankings and preferred choices were presented. A maximum of the top four choices are indicated. It is noteworthy that no non-renewable sources featured among the top four approaches. Wind was listed nine times, followed by hydro (8) and solar (6).

> The renewable energy sources (RES), i.e. articles 14 to 26 , most recurrently selected as an alternative were wind (10 times), followed by solar (9), hydro (9), and biomass (8). In seven of the 13 articles, rankings and preferred choices were presented. Again, a maximum of the top four choices are indicated in Table II. Wind was listed in all seven top ratings, solar in six, and hydro in two. Again, the same types of electricity sources as in the mixed articles were the preferred choices

> Column 5 represents the genre of criteria that the study used to evaluate the alternatives. However, only 16 of the 26 articles clearly subdivided the criteria into genres. With 14 listings, technological and environmental genres are used most frequently, followed by economic (11), socioeconomic-political (6) and social (6)

> Column 6 firstly shows the size of possible projects the MCDA was dealing with. It is divided into small-scale (up to $5 \mathrm{MW}$ ) and utility-scale (>5 MW). Secondly, the main stakeholder for the MCDA selection is given. In 19 publications the purpose was to find the best utilityscale alternative for a country's electricity demand, and in one publication for small-scale residential buildings. The project size was utility-scale in 20 articles and small-scale in one. The other articles did not specify the size or main stakeholder

> Column 7 indicates the types of decision-makers who were involved in identifying the evaluation criteria. In 19 MCDA approaches, decision-makers were not specified and a literature review was used. The other seven approaches used different types of decisionmakers depending on the objectives

> Columns 8 and 9 state the topic of the MCDA approach and the physical area of implementation. A regional implementation was found in 15 publications. Turkey had the highest implementation rate (5), followed by Spain (2) and Greece (2). Almost half (7) were within the European Union.

\section{Evaluation criteria in previous MCDA approaches}

This section provides an overview of the evaluation criteria that were used in the MCDA approaches from articles no. 1 to 26 in Table II. The listing of publications in column 1 of Table II is repeated in Table III to indicate how often criteria appeared in the literature. The most frequently recurring criteria are listed, and the number specifies the publication in which they appeared. In cases where criteria were used less than three times, they were categorized under 'Other'.

The criteria in Table III are divided into categories: technical, economic, and environmental and socio-political. This was based on the results of 'types of criteria' in column 6 of Table II. The technical category addresses the physical characteristics of the electricity alternative. The economic category investigates the financial feasibility. The environmental category evaluates the impact of the alternative on nature. Lastly, the socio-political category measures the influence on the quality of life of people affected by the project (Mateo, 2012).

The criteria used in the MCDA approaches are further subdivided into those used in approaches evaluating, on the one hand, mixed sources and on the other, only renewable energy sources. Criteria are noted only when they occur in more than three papers. The following provides a brief summary of the findings.

> Technical - the criteria indicate that overall 'efficiency' $(n=10)$, 'capacity factor' $(n=8)$, 'reliability' $(n=8)$ and 'maturity' ( $\mathrm{n}=7$ ) are most frequently evaluated. A strong difference in application between mixed and renewable sources can be seen with 'maturity'. It shows a higher regularity in the case of renewable energy sources

> Economic - this category shows that 'investment cost', with $n=18$, is predominantly used, followed by 'fixed and variable operation, and maintenance costs' $(n=11)$ and 'electricity costs' (LCOE). A significant difference can be seen with the criteria 'service life' and 'implementation period', which are used mostly with the renewable energy sources

- Environmental - the most frequently used criterion is 'external costs', with $n=16$. The external costs include different types of emissions. Some MCDA approaches specified the various emissions, while others summarized this aspect into one criterion. Further criteria are 'land use' $(n=10)$ and 'noise' $(n=4)$

$>$ Socio-political - the criteria illustrate that 'social acceptability' and 'job creation' were most regularly used, with $\mathrm{n}=10$. In addition, 'loss of life expectancy' was used in $n=6$. The criterion 'social benefit' was used only in mixed MCDA approaches. 


\section{A mining perspective on the potential of renewable electricity sources-Part 1}

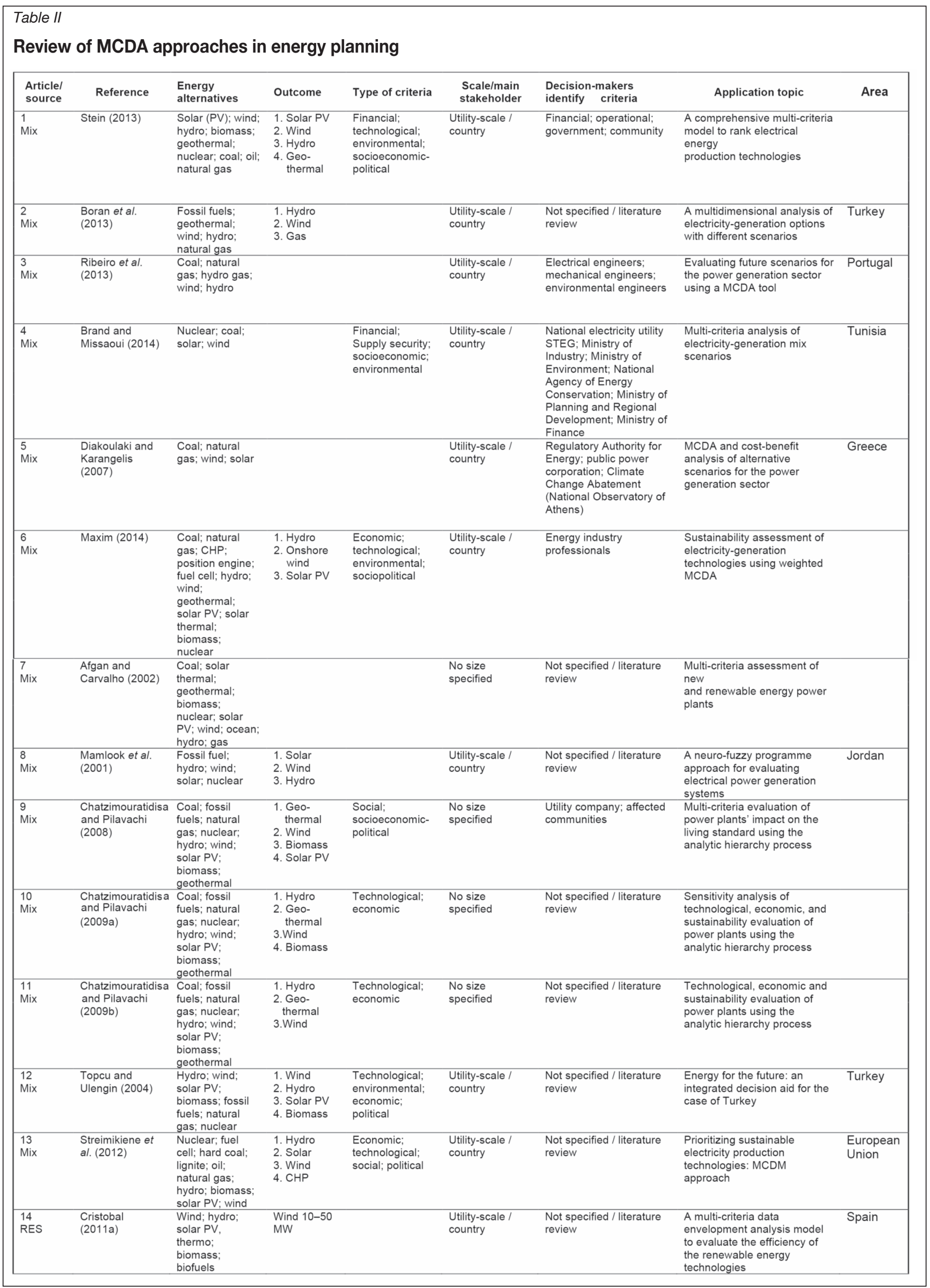




\section{A mining perspective on the potential of renewable electricity sources-Part 1}

\begin{tabular}{|c|c|c|c|c|c|c|c|c|}
\hline $\begin{array}{l}\text { Article/ } \\
\text { source }\end{array}$ & Reference & $\begin{array}{l}\text { Energy } \\
\text { alternatives }\end{array}$ & Outcome & Type of criteria & $\begin{array}{l}\text { Scale/main } \\
\text { stakeholder }\end{array}$ & $\begin{array}{l}\text { Decision-makers } \\
\text { identify criteria }\end{array}$ & Application topic & Area \\
\hline $\begin{array}{l}15 \\
\text { RES }\end{array}$ & Heo et al. (2010) & Not specified & & $\begin{array}{l}\text { Technological; } \\
\text { market; } \\
\text { economic; } \\
\text { environmental; } \\
\text { policy }\end{array}$ & $\begin{array}{l}\text { Utility-scale I } \\
\text { country }\end{array}$ & $\begin{array}{l}\text { Not specified / literature } \\
\text { review }\end{array}$ & $\begin{array}{l}\text { Analysis of the assessment } \\
\text { factors for renewable energy } \\
\text { dissemination programme } \\
\text { evaluation using fuzzy AHP }\end{array}$ & Korea \\
\hline $\begin{array}{l}16 \\
\text { RES }\end{array}$ & $\begin{array}{l}\text { Troldborg et al. } \\
(2014)\end{array}$ & $\begin{array}{l}\text { Wind; hydro; } \\
\text { geothermal; } \\
\text { solar PV; } \\
\text { biomass; heat- } \\
\text { pump; energy } \\
\text { from waste; } \\
\text { wave; tidal }\end{array}$ & $\begin{array}{l}\text { 1. Solar PV } \\
\text { 2. Heat } \\
\text { pumps } \\
\text { 3. Off-shore } \\
\text { wind }\end{array}$ & $\begin{array}{l}\text { Technical; } \\
\text { environmental; } \\
\text { socioeconomic }\end{array}$ & $\begin{array}{l}\text { Utility-scale / } \\
\text { country }\end{array}$ & $\begin{array}{l}\text { Not specified / literature } \\
\text { review }\end{array}$ & $\begin{array}{l}\text { Assessing the sustainability of } \\
\text { renewable energy } \\
\text { technologies using multi- } \\
\text { criteria analysis: Suitability of } \\
\text { approach for national-scale } \\
\text { assessments and associated } \\
\text { uncertainties }\end{array}$ & Scotland \\
\hline $\begin{array}{l}17 \\
\text { RES }\end{array}$ & $\begin{array}{l}\text { Ertay et al. } \\
(2013)\end{array}$ & $\begin{array}{l}\text { Hydro; wind; } \\
\text { solar PV; } \\
\text { biomass; } \\
\text { geothermal }\end{array}$ & $\begin{array}{l}\text { 1. Solar PV } \\
\text { 2. Wind }\end{array}$ & $\begin{array}{l}\text { Technological; } \\
\text { environmental; } \\
\text { economic; } \\
\text { sociopolitical }\end{array}$ & $\begin{array}{l}\text { Utility-scale / } \\
\text { country }\end{array}$ & $\begin{array}{l}\text { Not specified / literature } \\
\text { review }\end{array}$ & $\begin{array}{l}\text { Evaluation of renewable } \\
\text { energy alternatives using } \\
\text { MACBETH and fuzzy AHP } \\
\text { multi-criteria methods }\end{array}$ & Turkey \\
\hline $\begin{array}{l}18 \\
\text { RES }\end{array}$ & $\begin{array}{l}\text { Datta et al. } \\
(2011)\end{array}$ & $\begin{array}{l}\text { Solar PV; wind; } \\
\text { biomass; hydro }\end{array}$ & & & $\begin{array}{l}\text { No size } \\
\text { specified }\end{array}$ & $\begin{array}{l}\text { Not specified / literature } \\
\text { review }\end{array}$ & $\begin{array}{l}\text { Green energy sources (GES) } \\
\text { selection based on MCDA }\end{array}$ & \\
\hline $\begin{array}{l}19 \\
\text { RES }\end{array}$ & $\begin{array}{l}\text { Cristobal } \\
\text { (2011b) }\end{array}$ & $\begin{array}{l}\text { Wind; hydro; } \\
\text { solar-thermal; } \\
\text { biomass; bio } \\
\text { fuels }\end{array}$ & $\begin{array}{l}\text { 1. Biomass } \\
\text { 2. Wind } \\
\text { 3. Solar- } \\
\text { thermal }\end{array}$ & & $\begin{array}{l}\text { Utility-scale I } \\
\text { country }\end{array}$ & $\begin{array}{l}\text { Not specified / literature } \\
\text { review }\end{array}$ & $\begin{array}{l}\text { Multi-criteria decision-making } \\
\text { in the selection of a renewable } \\
\text { energy project in Spain: the } \\
\text { VIKOR method }\end{array}$ & Spain \\
\hline $\begin{array}{l}20 \\
\text { RES }\end{array}$ & $\begin{array}{l}\text { Kaya and } \\
\text { Kahraman } \\
(2010)\end{array}$ & $\begin{array}{l}\text { geothermal; } \\
\text { solar PV; wind; } \\
\text { hydro; biomass }\end{array}$ & $\begin{array}{l}\text { 1. Wind } \\
\text { 2. Solar PV } \\
\text { 3. Biomass } \\
\text { 4. Geo- } \\
\text { thermal }\end{array}$ & $\begin{array}{l}\text { Technical; } \\
\text { economic; } \\
\text { environmental; } \\
\text { social }\end{array}$ & $\begin{array}{l}\text { Utility-scale I } \\
\text { country }\end{array}$ & $\begin{array}{l}\text { Not specified / literature } \\
\text { review }\end{array}$ & $\begin{array}{l}\text { Multi-criteria renewable } \\
\text { energy planning using an } \\
\text { integrated fuzzy VIKOR and } \\
\text { AHP methodology for the } \\
\text { case of Istanbul }\end{array}$ & $\begin{array}{l}\text { Istanbul/ } \\
\text { Turkey }\end{array}$ \\
\hline $\begin{array}{l}21 \\
\text { RES }\end{array}$ & $\begin{array}{l}\text { Ahmad and } \\
\text { Tahar (2014) }\end{array}$ & $\begin{array}{l}\text { Hydro; solar PV; } \\
\text { biomass; biogas; } \\
\text { wind; multi solid } \\
\text { waste }\end{array}$ & $\begin{array}{l}\text { 1. Solar PV } \\
\text { 2. Biomass } \\
\text { 3. Hydro } \\
\text { 4. Wind }\end{array}$ & $\begin{array}{l}\text { Technical; } \\
\text { economic; } \\
\text { social; } \\
\text { environmental }\end{array}$ & $\begin{array}{l}\text { Utility-scale I } \\
\text { country }\end{array}$ & $\begin{array}{l}\text { Not specified / literature } \\
\text { review }\end{array}$ & $\begin{array}{l}\text { Selection of renewable energy } \\
\text { sources for sustainable } \\
\text { development of electricity } \\
\text { generation system using AHP } \\
\text { for the case of Malaysia }\end{array}$ & Malaysia \\
\hline $\begin{array}{l}22 \\
\text { RES }\end{array}$ & $\begin{array}{l}\text { Tsoutsos et al. } \\
(2009)\end{array}$ & $\begin{array}{l}\text { Wind; biomass; } \\
\text { hydro; solar PV }\end{array}$ & & $\begin{array}{l}\text { Technical; } \\
\text { economic; } \\
\text { environmental; } \\
\text { social }\end{array}$ & $\begin{array}{l}\text { Utility-scale I } \\
\text { country }\end{array}$ & $\begin{array}{l}\text { Local authorities; } \\
\text { potential investors; local } \\
\text { communities; academic } \\
\text { institutions; } \\
\text { environmental groups; } \\
\text { government and } \\
\text { European Union }\end{array}$ & $\begin{array}{l}\text { Sustainable energy planning } \\
\text { by using multi-criteria analysis } \\
\text { for application on the island of } \\
\text { Crete }\end{array}$ & $\begin{array}{l}\text { Crete/ } \\
\text { Greece }\end{array}$ \\
\hline $\begin{array}{l}23 \\
\text { RES }\end{array}$ & $\begin{array}{l}\text { Boran et al. } \\
(2012)\end{array}$ & $\begin{array}{l}\text { Solar PV; wind; } \\
\text { hydro; } \\
\text { geothermal }\end{array}$ & $\begin{array}{l}\text { 1. Hydro } \\
\text { 2. Wind } \\
\text { 3. Geo- } \\
\text { thermal } \\
\text { 4. Solar PV }\end{array}$ & & $\begin{array}{l}\text { Utility-scale / } \\
\text { country }\end{array}$ & $\begin{array}{l}\text { Not specified / literature } \\
\text { review }\end{array}$ & $\begin{array}{l}\text { Evaluation of renewable } \\
\text { energy technologies for } \\
\text { electricity generation in } \\
\text { Turkey using intuitionistic } \\
\text { fuzzy TOPSIS }\end{array}$ & Turkey \\
\hline $\begin{array}{l}24 \\
\text { RES }\end{array}$ & Lee et al. (2012) & Wind & & $\begin{array}{l}\text { Machine } \\
\text { characteristic; } \\
\text { economic; } \\
\text { environmental; } \\
\text { technical }\end{array}$ & $\begin{array}{l}\text { Utility-scale / } \\
\text { country }\end{array}$ & $\begin{array}{l}\text { Not specified / literature } \\
\text { review }\end{array}$ & $\begin{array}{l}\text { A wind turbine evaluation } \\
\text { model under a multi-criteria } \\
\text { decision-making environment }\end{array}$ & Taiwan \\
\hline $\begin{array}{l}25 \\
\text { RES }\end{array}$ & $\begin{array}{l}\text { Wang et al. } \\
(2008)\end{array}$ & $\begin{array}{l}\text { Stirling engine; } \\
\text { gas turbine; gas } \\
\text { engine; solid } \\
\text { oxide fuel cell }\end{array}$ & & $\begin{array}{l}\text { Technical; } \\
\text { economic; } \\
\text { environmental; } \\
\text { social }\end{array}$ & $\begin{array}{l}\text { Small-scale } \\
\text { (residential } \\
\text { building) }\end{array}$ & $\begin{array}{l}\text { Not specified / literature } \\
\text { review }\end{array}$ & $\begin{array}{l}\text { A fuzzy multi-criteria decision- } \\
\text { making model for tri- } \\
\text { generation system }\end{array}$ & \\
\hline $\begin{array}{l}26 \\
\text { RES }\end{array}$ & Cavallaro (2009) & $\begin{array}{l}\text { Parabolic } \\
\text { trough; parabolic } \\
\text { DSG; SCR } \\
\text { molten salt; SCR } \\
\text { saturated St.; } \\
\text { SCR phoebus; } \\
\text { solar hybrid gas; } \\
\text { dish-Stirling }\end{array}$ & $\begin{array}{l}\text { 1. SCR } \\
\text { molten sal } \\
\text { 2. Parabolic } \\
\text { DSG }\end{array}$ & & Utility-scale & $\begin{array}{l}\text { Not specified / literature } \\
\text { review }\end{array}$ & $\begin{array}{l}\text { Multi-criteria decision aid to } \\
\text { assess concentrated solar } \\
\text { thermal technologies }\end{array}$ & \\
\hline
\end{tabular}

\section{Impact on the MCDA approach for mining corporations}

The purpose of this paper, as stated in the Introduction, is to investigate the internal evaluation process regarding possible electricity sources for mining corporations in South Africa. This will contribute to the foundation of an MCDA approach for mining corporations in South Africa to optimize the evaluation of electricity generation sources. The literature review provides an overview of how MCDA approaches have been used in energy planning in past years. The following points indicate how they contributed to, or affected, the identification of the criteria of this paper.

> Not one MCDA approach in energy planning could be found from the perspective of a corporate entity. Consequently, the previously used criteria can be used only as an indication

> The only MCDA approach to energy planning on the African continent was in Tunisia. No such approach to energy planning was found in South Africa
The overview of previously used evaluation criteria assists in selecting the criteria for mining corporations. As the marketing of renewable energy to mining corporations is relatively new, respondents might not include all important criteria for renewable sources. The listed criteria of energy planning serve as a checklist and might indicate that further investigations have to be conducted

> The types of criteria used in previous publications provide a solid indication about which are important for the evaluation of electricity generation sources

> The overall preferred selection of solar, wind, and hybrid technologies indicates the renewable alternatives that should be included in the MCDA approach for mining corporations.

\section{Foundations to the internal evaluation process}

\section{Type of alternatives to be evaluated}

As the main purpose of this paper is to provide more 


\section{A mining perspective on the potential of renewable electricity sources-Part 1}

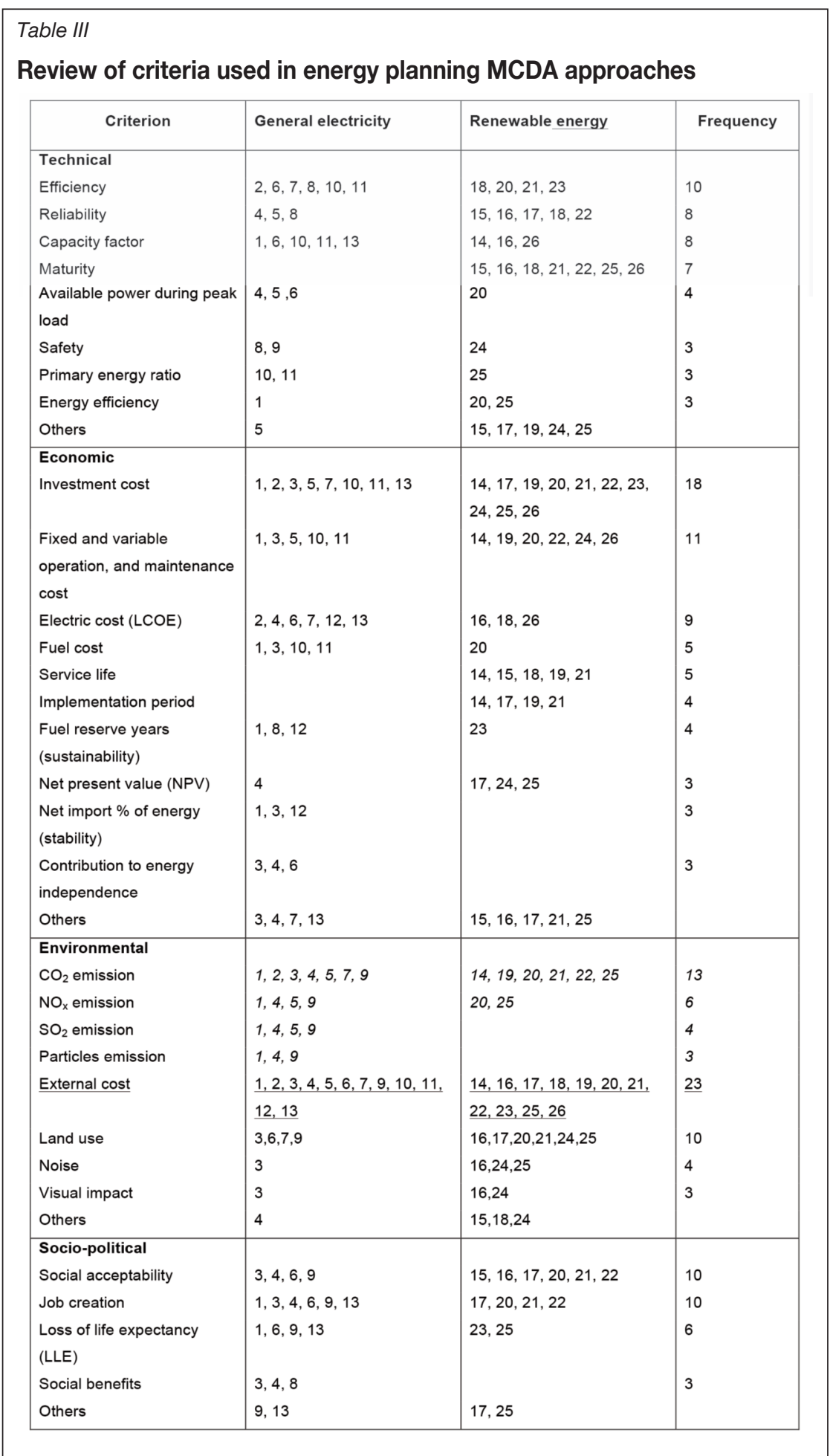

information about the criteria used by mining corporations to evaluate possible electricity sources, with the final outcome of being able to compare renewable with current sources, it is important to define the exact characteristics of the types of alternatives available. The purpose of specifying the selection standards for alternatives is to create more transparency in the process of analysing and evaluating them by comparing them with each other (Stewart and Belton, 2002). In cases where alternatives are too different in nature, it becomes more difficult and less informative to compare them according to the same criteria (Keeney, 1996).

Earlier research by Votteler and Brent (2016) investigated the external macroeconomic environment to reveal the potential of renewable sources for mining corporations in South Africa. Based on this research and the previous MCDA applications in energy planning, solar PV, 


\section{A mining perspective on the potential of renewable electricity sources-Part 1}

onshore wind power, and 'hot dry rock' geothermal power were selected as the renewable sources with the greatest potential. Owing to the intermittency, especially of solar PV and wind power, and the constant electricity demand of mining operations, hybrid versions with current electricity sources were identified as the best option.

In addition, based on the current legislative and regulatory framework in South Africa, the business model of self-generation ${ }^{3}$, in the form of own investment or a power purchase agreement, has the greatest potential. As the purpose of the development of the MCDA for mining corporations was to create more transparency, own investment was selected. The reason for this choice was to focus the attention on the performance of the technology and not on third parties (Boyse et al., 2014).

Therefore, decision-makers at mining corporations were asked to list the evaluation criteria that they would use to evaluate the following electricity sources:

$>$ Diesel generator

> Hybrid diesel generator / solar PV

> Hybrid diesel generator / onshore wind power

> Hybrid diesel generator / geothermal power

$>$ Eskom grid connected

> Hybrid Eskom grid connected / solar PV

> Hybrid Eskom grid connected / onshore wind power

> Hybrid Eskom grid connected / geothermal power.

\section{Stakeholders}

The business model has great influence on the type and number of stakeholders involved in establishing an electricity source for mining operations. All stakeholders and their influence on the decision-making process have to be identified to ensure that the best possible solution can be found (Boyse et al., 2014). The selected model of selfgeneration and own investment involved three main stakeholders: the mining corporation, the project developer, and the legislative and regulatory body.

The mining corporation was the main stakeholder for the purpose of this research, as it is the decision-maker regarding a possible project realization. The decision-makers have to cover two main areas: operations and finance. Decision-makers selecting an alternative from an operational perspective will make use of criteria that ensure that the generating source will satisfy the electricity demands of the mine (Cookie et al., 2007). Decision-makers selecting an alternative from a financial perspective will make use of criteria to find the most feasible alternative for electricity generation at the mining location (Goh et al., 2014).

The project development company is responsible for the realization of the alternative. The companies represent the different electricity sources and will provide the data necessary to feed the evaluation criteria to execute the MCDA approach. The developer has no direct influence on the decision-making, and can only affect the attractiveness of the project (Lerro, 2011; Aslani, 2014).

The regulatory and legislative body in South Africa dictates the framework regarding the business model of how

\footnotetext{
3. The mining corporation develops its own on-site renewable generation source (Boyse et al., 2014).
}

electricity projects will be realized. As previously stated, according to this framework the model of self-generation was selected as the most lucrative. It further influences the actual development of the project with factors like compulsory environmental assessments, which also consider the surrounding communities (Lerro, 2011; Frost, 1995).

\section{Research results}

\section{Profile of mining corporations}

To reveal the criteria that mining corporations use to evaluate possible electricity generation sources, four different mining corporations were included in this study, as illustrated in Table IV. In three the respondents were electrical engineers, and in one case the manager of a utility supply chain with responsibility for six mines. Emphasis was placed on gaining information from a variety of mines with different resources, sizes, and targets in order to gain optimal insight. The resources mined were gold, coal, chrome, and zircon. The average annual electricity consumption per mine varied from 4.2 GWh to $2752 \mathrm{GWh}$. As the Eskom tariff varies according to factors like season or time of day, the yearly average price was stated for the sake of simplicity. All mines were connected to the grid, with diesel generators as backup systems. One of the mines had installed a $1 \mathrm{MW}$ solar PV plant, and two other corporations were conducting solar PV and onshore wind power feasibility studies.

\section{Criteria characteristics and requirements}

To structure the internal evaluation process, a decision table was developed. The table of mining corporations evaluating different alternatives for electricity sources had to be constructed according to certain characteristics. The decision table was based on the results of the post-it mind-maps from the interviews with decision-makers. To be able to identify a clear structure and to use the criteria for further analysis in a MCDA approach, specific requirements had to be fulfilled by each criterion (Stewart and Belton, 2002).

> Value relevance - the decision-maker has to be able to relate the concept to the aim of the mining corporation, which enables him or her to define a clear preference for the criterion

> Understandability - the criterion has to be clearly identified and explained. Each person involved in the decision-making process has to know the exact meaning to prevent any confusion and misleading results (Edwards et al., 2007)

> Measurability-it has to be possible to measure each criterion in a consistent manner according to the alternatives being analysed. As the decision table is the foundation of an MCDA analysis, this requirement is important to create meaningful results

> Non-redundancy-there should not be more than one criterion measuring the same factor. A negative result would be to have faulty results, e.g. one factor has too much weight because it was counted more than once (Edwards et al., 2007)

> Judgmental independence-one criterion should not have significant influence on the performance of another criterion (Loken, 2007)

> Balancing completeness and conciseness-all aspects of 


\section{A mining perspective on the potential of renewable electricity sources-Part 1}

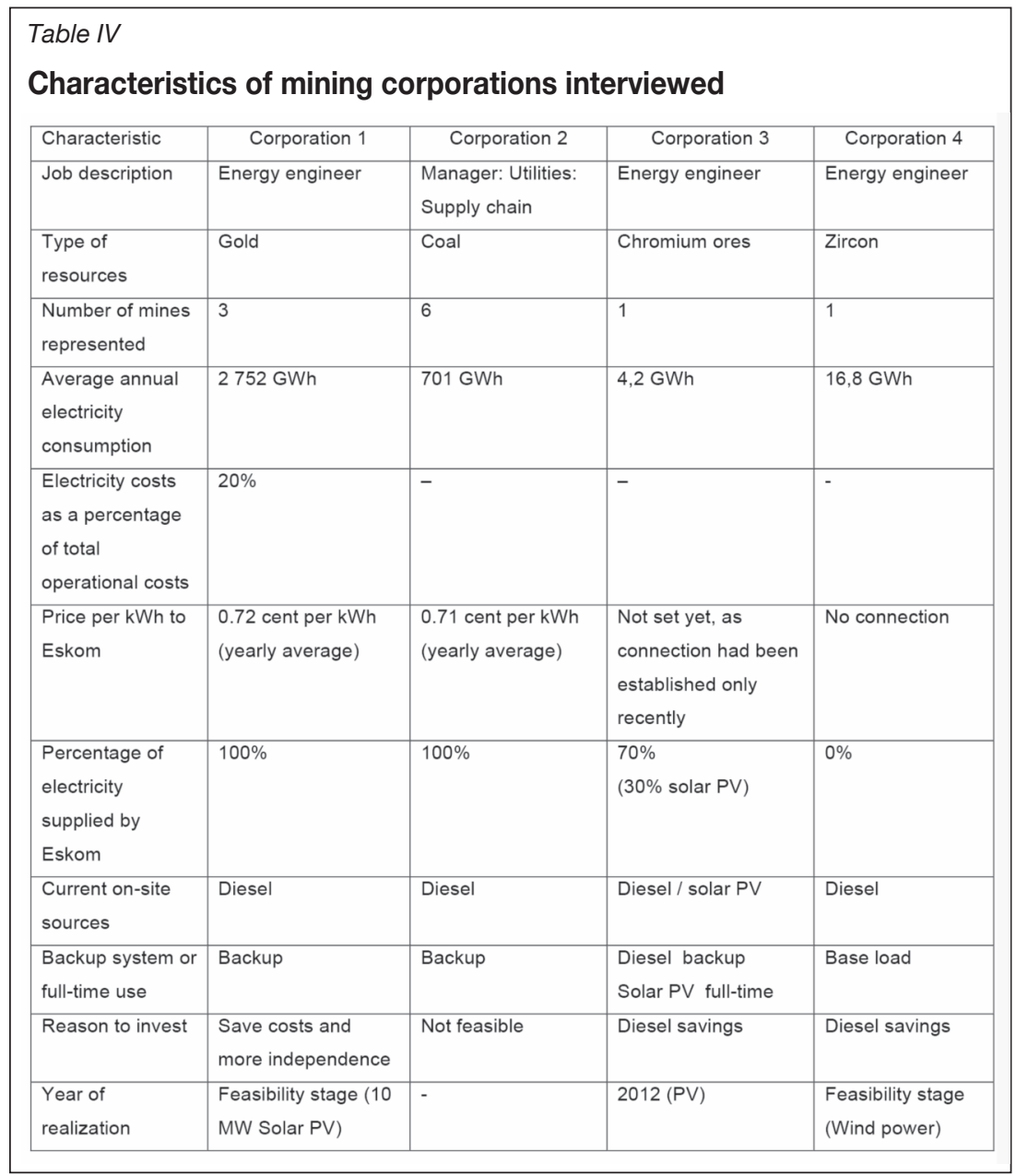

alternatives in a decision process have to be addressed by the selected criteria. However, when selecting too many criteria the researcher has to beware of omitting to consider the previously mentioned requirements (Edwards et al., 2007; Loken, 2007)

> Operationally—criteria should not be only theorybased, but should also be practically proven.

\section{The decision criteria}

The interviews with the mining corporations showed that possible electricity sources were evaluated based on their being independent and able to supply electricity (including the necessary fuel) on their own, and within the investment capability of the corporation. The criteria are listed and described in Table V. The first column provides the category and the second the criteria.

The economic category included two criteria that measured the economic value of the electricity source, namely: levelized electricity costs and net present value. These criteria used several values as part of the calculation. The prediction of fuel costs was new in regard to the literature review. Further new criteria were supply 24/7, service level, corporate image, and effect on community.

It is important to mention that the criteria listed in Table $\mathrm{V}$ represent a summary of all criteria used during the evaluation process, and that most had been applied in other energy planning evaluations at various points in time. The sequence started with technological criteria, aimed to ensure that the potential electricity source could satisfy the electricity requirements of the mining operation. Thereafter, technologies that passed the technical criteria were analysed according to economic criteria. Lastly, environmental and social criteria were evaluated.

Mining corporations have peculiarities not found in previous MCDA evaluations. Firstly, mining operations are more profit-oriented in comparison to national electricity providers. Therefore, criteria like initial investment cost, which can have a considerable influence on the balance sheet in the first years, have higher priority for mining corporations than for electricity providers. Secondly, owing to the limited mix of electricity sources and the requirement of constant electricity supply, the criteria of reliability and supply 24/7 are more important to mines. Both were therefore used as prerequisites in the choice of the type of electricity source to be evaluated in Table V. Another criterion that had to be considered, which did not feature in previous evaluations, was the predicted lifespan of the mine, as this factor has a considerable influence on the economic criteria, and consequently on the feasibility of the project.

\section{Conclusion}

The preparation of this paper is justified by two facts. Firstly, the difficulties with current electricity sources in South Africa have increased the attractiveness of the steadily advancing renewable technologies for mining operations in the country. 


\section{A mining perspective on the potential of renewable electricity sources-Part 1}

\begin{tabular}{|c|c|c|}
\hline \multicolumn{3}{|c|}{ Table $V$} \\
\hline \begin{tabular}{|l} 
First \\
hierarchy \\
criteria
\end{tabular} & Second hierarchy criteria & Description \\
\hline \multirow[t]{7}{*}{ Economy } & Investment cost & $\begin{array}{l}\text { Includes all costs regarding the planning, purchase, and } \\
\text { installation of the electricity source. }\end{array}$ \\
\hline & $\begin{array}{l}\text { Operating and } \\
\text { maintenance costs }\end{array}$ & $\begin{array}{l}\text { Operating costs entail employees' salaries, the money spent } \\
\text { on the energy (fuel), and the products and services for the } \\
\text { system's operation. Maintenance costs ensure that the } \\
\text { system is in operating condition, in order to prolong the } \\
\text { system's life and avoid failures that result in downtime. }\end{array}$ \\
\hline & Prediction of fuel costs & $\begin{array}{l}\text { Provides a prediction of the price of fuel consumed to } \\
\text { produce electricity. }\end{array}$ \\
\hline & $\begin{array}{l}\text { Prediction of initial } \\
\text { investment costs }\end{array}$ & $\begin{array}{l}\text { Provides an estimation of how the initial investment cost will } \\
\text { develop. If the technology is relatively new, possible price } \\
\text { drops can be expected. }\end{array}$ \\
\hline & Annual cost of electricity & $\begin{array}{l}\text { Measures the annual cost of electricity per kWh. It compares } \\
\text { annual costs to annual output, without initial investment } \\
\text { costs. }\end{array}$ \\
\hline & Levelized electricity cost & $\begin{array}{l}\text { Measures the rand cost per kWh, including all costs incurred } \\
\text { by the initial investment till the end of the predicted lifetime - } \\
\text { which is placed in relation with the projected output of kWh in } \\
\text { the same time span. }\end{array}$ \\
\hline & Net present value & $\begin{array}{l}\text { This is a financial method to define the total present value of } \\
\text { a series of annual cash inflows and outflows during the } \\
\text { lifespan of the asset. The cash flows are discounted back to } \\
\text { their present and summed. The final present amount is } \\
\text { compared to the initial investment cost. }\end{array}$ \\
\hline \multirow[t]{7}{*}{ Technology } & Efficiency & $\begin{array}{l}\text { Indicates the ratio of output energy to input energy. It } \\
\text { explains how much useful energy can be generated. }\end{array}$ \\
\hline & Safety & $\begin{array}{l}\text { Relates to the degree of safety for employees working on } \\
\text { site. }\end{array}$ \\
\hline & Implementation period & The amount of time needed to realize the project. \\
\hline & Reliability & $\begin{array}{l}\text { The capacity of a system to perform as designed and } \\
\text { planned. }\end{array}$ \\
\hline & Supply $24 / 7$ & Most mining operations need a 24 -hour electricity supply. \\
\hline & Maturity & $\begin{array}{l}\text { Refers to the development stage of the technology. The } \\
\text { stages range from 'only tested in laboratories' to 'close to } \\
\text { reaching the theoretical limits of efficiency'. }\end{array}$ \\
\hline & Service level & $\begin{array}{l}\text { Measures the availability of experts and spare parts to repair } \\
\text { damaged equipment. }\end{array}$ \\
\hline \multirow[t]{3}{*}{ Environment } & $\mathrm{CO}_{2}$ emission & $\begin{array}{l}\text { Represents the measurement of the emission of a } \\
\text { colourless, odourless and tasteless gas, which is mainly } \\
\text { emitted through the combustion of coal, oil and gas. }\end{array}$ \\
\hline & Noise & $\begin{array}{l}\text { The machine-created sound that disrupts human and animal } \\
\text { daily life. }\end{array}$ \\
\hline & Land requirement & $\begin{array}{l}\text { Represents the amount of land that the electricity source } \\
\text { requires to produce at a certain capacity. }\end{array}$ \\
\hline
\end{tabular}




\section{A mining perspective on the potential of renewable electricity sources-Part 1}

Table $V$
Evaluation criteria of mining corporations
\begin{tabular}{|l|l|l|}
\hline Social & Job creation & $\begin{array}{l}\text { The number of people employed during the life cycle of an } \\
\text { energy system. }\end{array}$ \\
\hline & Corporate image & $\begin{array}{l}\text { The possible impact of the electricity source on the corporate } \\
\text { identity in the minds of diverse publics, such as customers, } \\
\text { investors, and employees. }\end{array}$ \\
\hline & Effect on community & $\begin{array}{l}\text { Refers to the possible impact on the surrounding residents, } \\
\text { after the decision to close the mine. The community could } \\
\text { further utilize the electricity source. }\end{array}$ \\
\hline
\end{tabular}

Secondly, previous research has been directed only at investigating the external influences on this market.

The contribution of this paper is an investigation of the internal business approach of mining corporations towards evaluating electricity generation sources. This research has shown that the MCDA method is the most suitable approach. No application of the MCDA method in energy planning from the perspective of corporate or mining entities could be found - most MCDA adaptations were from the perspective of governmental bodies or general electricity source evaluations without a specific perspective. In addition, no adaptation of MCDA methods in energy planning has been conducted in a South African context. Consequently, in the absence of data, qualitative interviews were conducted with four mining corporations operating in South Africa to reveal the criteria that these organizations applied in order to evaluate possible electricity sources. The differences found between the selection criteria used by the four corporations and those of previous approaches in the literature are the result of different perspectives. Mines are profit-oriented business entities and electricity generation is not their core business, while previous approaches were more focused on the technological and environmental factors.

This paper has established the basis for evaluating and comparing current and renewable electricity-generating options from the perspective of mining corporations in South Africa. The reason for subdividing the work into two papers was to create a basis of two components: the first being the current knowledge about the external framework; while the second reveals the internal framework. Part 2 will fuse the external and internal components in order to apply the adapted MCDA framework and to feed the model with realtime data.

\section{References}

AfGan, N.H. and CarvalHo, M.G. 2002. Multi-criteria assessment of new and renewable energy power plants. Energy, vol. 27, no. 8. pp. 739-755.

AHMAD, S. and TAHAR, R.M. 2014. Selection of renewable energy sources for sustainable development of electricity generation system using analytic hierarchy process: A case of Malaysia. Renewable Energy, vol. 63. pp. $458-466$.

Alton, T., Arndt, C., Davies, R., Hartley, F., Markrelov, K., Thurlow, J., and UвoGu, D. 2014. Introducing carbon taxes in South Africa. Applied Energy, vol. 116, March. pp. 344-354

AsLAnI, A. 2014. Private sector investment in renewable energy utilization: Strategic analysis of stakeholder perspectives in developing countries. International Journal of Sustainable Energy, vol. 33, no.1. pp. 112-124.
Boran, F.E., Boran, K., and MENLIK, T. 2012. The evaluation of renewable energy technologies for electricity generation in Turkey using intuitionistic Fuzzy TOPSIS. Energy Sources, Part B: Economics, Planning, and Policy, vol. 7 , no. 1. pp. 81-90.

Boran, F.E., Dizdar, E., Toktas, I., Boran, K., Eldem, C., and Asal, Ö. 2013. A multidimensional analysis of electricity generation options with different scenarios in Turkey. Energy Sources, Part B: Economics, Planning, and Policy, vol. 8, no. 1. pp. 44-55.

Boyse, F., Causevic, A., Duwe, E., and Orthofer, M. 2014. Sunshine for mines: Implementing renewable energy for off-grid operations. Carbon War Room, Washington, DC.

BRAND, B. and Missaoui, R. 2014. Multi-criteria analysis of electricity generation mix scenarios in Tunisia. Renewable and Sustainable Energy Reviews, vol. 39. pp. 251-261.

Cavallaro, F. 2009. Multi-criteria decision aid to assess concentrated solar thermal technologies. Renewable Energy, vol. 34, no. 7. pp. 1678-1685.

Cetindamar, D., Daim, T.D., Beyhan, B., and Basoglu, N. 2013. Strategic Planning Decisions in the High Tech Industry. Springer Verlag, London.

Chatzimouratidisa, A.I. and Pilavachi, P.A. 2008. Multicriteria evaluation of power plants impact on the living standard using the analytic hierarchy process. Energy Policy, vol. 36, no. 3. pp. 1074-1089.

Chatzimouratidisa, A.I. and Pilavachi, P.A. 2009a. Sensitivity analysis of technological, economic and sustainability evaluation of power plants using the analytic hierarchy process. Energy Policy, vol. 37, no. 3. pp. 788-798.

Chatzimouratidisa, A.I. and Pilavachi, P.A. 2009b. Technological, economic and sustainability evaluation of power plants using the analytic hierarchy process. Energy Policy, vol. 37, no. 3. pp. 778-787.

CHISLETT, M. 2014. Cleaner energy at stable prices: The value proposition of solar for mines. Interview. Toronto, Energy and Mines.

CookIE, R., CRIPPs, A., IRwin, A., and KoLoKotroni, M. 2007. Alternative energy technologies in buildings: Stakeholder perception. Renewable Energy, vol. 32 , no. 14. pp. 2320-2333.

CRISTOBAL, J.R.S. 2011a. A multi criteria data envelopment analysis model to evaluate the efficiency of the renewable energy technologies. Renewable Energy, vol. 36, no. 10. pp. 2742-2746.

CRISTOBAL, J.R.S. 2011b. Multi-criteria decision-making in the selection of a renewable energy project in Spain: The Vikor method. Renewable Energy, vol. 36, no. 2. pp. 498-502.

Datta, A., Ray, A., BhatTacharya, G., and Saha, H. 2011. Green energy sources (GES) selection based on multi-criteria decision analysis (MCDA) International Journal of Energy Sector Management, vol. 5, no. 2. pp. 271-286.

DE BEER, A.J. 2000. The development of a generic model for strategic planning for small and medium manufacturing enterprises in a turbulent environment. MBA dissertation, Stellenbosch University, South Africa.

DiaKoulaKi, D. and Karangelis, F. 2007. Multi-criteria decision analysis and cost-benefit analysis of alternative scenarios for the power generation sector in Greece. Renewable and Sustainable Energy Reviews, vol. 11, no. 4. pp. 716-727. 


\section{A mining perspective on the potential of renewable electricity sources-Part 1}

Edwards, W., Miles, R.F., and von Winterfeldt, D. 2007. Advances in Decision Analysis: From Foundations to Applications. Cambridge University Press, Cambridge.

EIUG (Energy Intensive User Group of Southern Africa). 2015. Electricity cos as a percentage of annual expenditure. http://www.eiug.org.za/about/ membership/ [accessed 11 Jun. 2015].

ENERGY and MINES. 2015. Introduction to renewable energy with mining operations. http://energyandmines.com [accessed 26 May 2015].

ERTAY, T., KAHRAMAn, C., and KAYA, I. 2013. Evaluation of renewable energy alternatives using MACBETH and fuzzy AHP multi criteria methods: The case of Turkey. Technological and Economic Development of Economy, vol. 19 , no. 1. pp. 38-62.

ESKOM. 2015a. Company information. http://www.eskom.co.za/OurCompany/ CompanyInformation/Pages/Company_Information_1.aspx [accessed 10 Jun. 2015].

ESKOM. 2015b. Tariff and charges. http://www.eskom.co.za/CustomerCare/ TariffsAndCharges/Pages/Tariffs_And_Charges.aspx [accessed 13 Jun. 2015].

Frost, F.A. 1995. The use of stakeholder analysis to understand ethical and moral issues in the primary resource sector. Journal of Business Ethics, vol. 14 , no. 8. pp. 653-661.

GoH, H.H., LeE, S.W., ChuA, Q.S., Goн, K.C., Кок, B.C., and Teо, K.T.K. 2014. Renewable energy project management, challenges and risk. Renewable and Sustainable Energy Reviews, vol. 38. pp. 917-932.

GovenDER, S. 2008. Energy saving mechanisms in the mining industry: A case study of switching off non-essential power. MBA thesis, Stellenbosch University, South Africa.

Hague, P.N., and Jackson, P. 1995. Do Your Own Market Research. Kogan Page, London.

Heo, E., KIM, J., and Boo, K. 2010. Analysis of the assessment factors for renewable energy dissemination program evaluation using fuzzy AHP. Renewable and Sustainable Energy Reviews, vol. 14, no. 8. pp. 22142220.

IsHizAKA, A., and NemerY, P. 2013. Multi-criteria Decision Analysis, Wiley, Chichester, UK.

JАкнотіуа, G.P. 2013. Strategic Planning, Execution, and Measurement (SPEM). Taylor \& Francis, Boca Raton, FL.

JuDD, E. 2014. Sincerity and patience required for renewables in mining sector. Energy and Mines, Toronto.

KAPLAN, S., and NoRTon, D.P. 1992. The balanced scorecard - measures that drive performance. Harvard Business Review, vol. 70, no. 1. pp 71-79.

KAYA, T., and KaHRAman, C. 2010. Multi criteria renewable energy planning using an integrated fuzzy VIKOR \& AHP methodology: The case of Istanbul. (Report). Energy, vol. 35, no. 6. pp. 2517-2527.

KeEnEy, R.L. 1996. Value-focused thinking: Identifying decision opportunities and creating alternatives. European Journal of Operational Research, vol. 92, no. 3. pp. 537-549.

KIng, W. and Cleland, D. 1987. Strategic Planning and Management Handbook. Van Nostrand Reinhold, New York, NY.

Lee, A.H.I., Hung, M., Kang, H., and Pearn, W.L. 2012. A wind turbine evaluation model under a multi-criteria decision making environment. (Report). Energy Conversion and Management, vol. 64. pp. 289-300.

LERRo, A. 2011. A stakeholder-based perspective in the value impact assessment of the project "Valuing intangible assets in Scottish renewable SMEs". Measuring Business Excellence, vol. 15, no. 3. pp. 3-15.

LINARD, K.L. and Yoon, J. 2000. The dynamics of organizational performance development of a dynamic balanced scorecard. Proceedings of the 1 st International Conference on Systems Thinking in Management, Geelong, Australia, 8-10 November.

LOKEN, E. 2007. Multi-criteria planning of local energy systems with multiple energy carriers. Doctoral thesis, Norwegian University of Science and Technology, Norway.
MAMLOOK, R., AKASH, B.A., and MoHSEn, M.S. 2001. A neuro-fuzzy program approach for evaluating electric power generation systems. Energy, vol. 26, no. 6. pp. 619-632.

MAteo, J.R.S.C. 2012. Multi Criteria Analysis in the Renewable Energy Industry. Springer Verlag, London.

MAXıм, A. 2014. Sustainability assessment of electricity generation technologies using weighted multi-criteria decision analysis. Energy Policy, vol. 65. pp. 284-297.

NEWTon, N. 2010. The use of semi-structured interviews in qualitative research: Strengths and weaknesses. http://www.academia.edu/1561689/The_use_of_semistructured_interviews_in_qualitative_research_strengths_and_weaknesses [accessed 24 May 2014].

NicoLAs, F. 2014. Africa-focused miners positioned to embrace 100\% renewable energy. Mining Weekly, 21 May.

http://www.miningweekly.com/article/africa-focused-miners-positionedto-embrace-100-renewable-energy-2014-05-21 [accessed 2 Jun. 2015].

NumBi, B.P., ZhAng, J., and XIA, X. 2014. Optimal energy management for a jaw crushing process in deep mines. Energy, vol. 68, April. pp. 337-348.

Person, R. 2013. Balanced Scorecards \& Operational Dashboards with Microsoft Excel. 2nd edn. Wiley, Indianapolis.

Petticrew, M., and Roberts, H. 2006. Systematic Reviews in the Social Sciences: A Practical Guide. Blackwell, Oxford.

Powell, C. 2003. The Delphi technique: Myths and realities. Journal of Advanced Nursing, vol. 41, no. 4. pp. 376-382.

Ribeiro, F., Ferreira, P., and Araujo, M. 2013. Evaluating future scenarios for the power generation sector using a multi-criteria decision analysis (MCDA) tool: The Portuguese case. Energy, vol. 52. pp. 126-136.

RoEHRL, R. and RIAHI, K. 2000. Technology dynamics and greenhouse gas emissions mitigation: A cost assessment. Technological Forecasting \& Social Change, vol. 63, no. 2. pp. 231-261.

STEIN, E.W. 2013. A comprehensive multi-criteria model to rank electric energy production technologies. (Report). Renewable and Sustainable Energy Reviews, vol. 22. pp. 640-654

Steinhaeuser, I., Sethia, A., Jaiswal, S., Rocha Oliveira, G., Sekine, Y., and ALVES, L.C. 2012. Global Corporate Renewable Energy Index (CREX). Bloomberg New Energy Finance \& Vestas, Copenhagen.

Stewart, T.J. and Belton, V. 2002. Multi Criteria Decision Analysis: An Integrated Approach. Kluwer, Dordrecht.

Streimikiene, D., Balezentis, T., Krisciukaitien, A.I., and Balezentis, A. 2012. Prioritizing sustainable electricity production technologies: MCDM approach. (Report). Renewable and Sustainable Energy Reviews, vol. 16, no. 5. pp. 3302-3311.

Topcu, Y.I. and UlEngin, F. 2004. Energy for the future: An integrated decision aid for the case of Turkey. Energy, vol. 29, no. 1. pp. 137-154

Troldborg, M., Heslop, S., and Hough, R.L. 2014. Assessing the sustainability of renewable energy technologies using multi-criteria analysis: Suitability of approach for national-scale assessments and associated uncertainties. Renewable and Sustainable Energy Reviews, vol. 39. pp. 1173-1184.

Tsoutsos, T., Drandaki, M., FrantZeskaki, N., Losifidis, E., and Kiosses, I. 2009. Sustainable energy planning by using multi-criteria analysis application in the island of Crete. Energy Policy, vol. 37, no. 5. pp. 1587-1600.

VotTelER, R.G. and BRENT, A.C. 2017. A mining perspective on the potential of renewable electricity sources for operations in South Africa: Part 2. A multi-criteria decision assessment. Journal of the Southern African Institute of Mining and Metallurgy, vol. 117, no. 3. pp. 299-312.

WANG, J., Jing, Y., ZHANG, C., SHI, G., and ZHANG, X. 2008. A fuzzy multi-criteria decision-making model for trigeneration system. Energy Policy, vol. 36 no. 10. pp. 3823-3832.

Westermann, G., and SeHL, I. 2006. Developing a balanced scorecard based benchmarking approach for tourist destinations. Proceedings of the European Innovation Pressure Conference, Tampere, Finland, 15-17, March. 